\title{
Native and exotic plant species diversity in forest fragments and forestry plantations of a coastal landscape of central Chile
}

\author{
Diversidad de plantas nativas y exóticas en fragmentos de bosque \\ y plantaciones forestales en un paisaje costero de Chile central
}

\author{
Pablo I Becerra ${ }^{a *}$, Javier A Simonetti ${ }^{\text {b }}$ \\ *Autor de correspondencia: a Pontificia Universidad Católica de Chile, Facultad de Agronomía e Ingeniería Forestal, \\ Departamento de Ecosistemas y Medio Ambiente, Center of Applied Ecology and Sustainability (CAPES), \\ Av. Vicuña Mackenna 4860, Santiago, Chile, pablobecerra@uc.cl

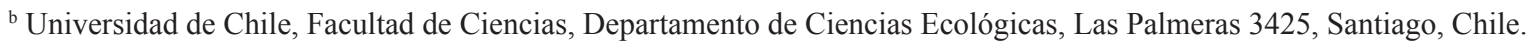

\begin{abstract}
SUMMARY
Native forest replacement by exotic forestry plantations and fragmentation may have different consequences for biodiversity. In the transition zone between the Mediterranean and Temperate Regions of Chile, native forests have been replaced and fragmented, and currently are surrounded by Pinus radiata plantations. However, the effects of these changes on biodiversity are still poorly understood. In this study, we evaluated how the replacement and fragmentation of these native forests have affected plant communities of a coastal area of the Maule Region in central Chile. We compared plant communities between three types of landscape units: pine plantations, small forest fragments and a continuous native forest. On each landscape unit, we evaluated richness and composition of native and exotic species on $100 \mathrm{~m}^{2}$ plots located in two positions: edge and interior. Native species richness decreased and exotic invasion increased in plantations compared to fragments and continuous forests. Fragmentation increased invasion of exotic species, nonetheless did not affect native species richness. Small fragments were significantly similar to the continuous forest in native species composition ( $\sim 52 \%$ similarity). Exotic species composition of the plantation was significantly similar to edges of fragments (> 53\% similarity). Our results suggest that, although several native species may inhabit pine plantations, these are not able to support as many native plants as do native forests. Furthermore, plantations facilitate exotic invasion. Despite that fragments have been invaded, the fact that many native species are growing there suggests that small fragments of native forest may be considered as high-value areas for conservation.
\end{abstract}

Key words: alien species, biodiversity, invasion, replacement, forestry plantation, fragmentation.

\section{RESUMEN}

Los bosques nativos de la zona transicional entre las regiones de clima mediterráneo y templado del sur de Chile han sido reemplazados y fragmentados, y actualmente están rodeados de plantaciones de Pinus radiata. Sin embargo, aún se conocen poco los efectos de estos cambios en la biodiversidad. En este estudio evaluamos el efecto del reemplazo y fragmentación del bosque nativo sobre las comunidades vegetales de un área costera de la región del Maule, Chile. Para esto, comparamos las comunidades vegetales entre tres tipos de unidades de paisaje: plantaciones de pino, pequeños fragmentos de bosque nativo, y un bosque nativo continuo. En cada unidad de paisaje evaluamos la riqueza y composición de especies en parcelas de $100 \mathrm{~m}^{2}$ ubicadas en dos posiciones: borde e interior. La riqueza de especies nativas decreció y la invasión de exóticas aumentó en las plantaciones comparado a fragmentos y bosque continuo. La fragmentación aumentó la invasión de plantas exóticas, pero no afectó la riqueza de especies nativas. Los fragmentos fueron significativamente similares al bosque continuo en composición de nativas ( $52 \%)$. La composición de exóticas de la plantación fue significativamente similar a bordes de fragmentos $(>53 \%)$. Los resultados sugieren que, aunque diversas especies nativas pueden habitar en plantaciones de $P$. radiata, estas no pueden albergar tan alta diversidad como los bosques nativos, y en cambio facilitan la invasión. Además, aunque los fragmentos han sido invadidos, poseen una importante riqueza de especies nativas y pueden ser considerados como áreas de alto valor de conservación.

Palabras clave: biodiversidad, especies exóticas, fragmentación, invasión, plantaciones forestales, reemplazo de bosque nativo.

\section{INTRODUCTION}

Changes in land uses of forest ecoregions have produced landscapes that may include contrasting ecosystem types, such as native forest fragments of different sizes, forestry exotic plantations, agricultural crops, urban areas and roads (Groom and Schumaker 1993, Bustamante and Castor 1998). The resulting habitat loss and fragmentation 
have been considered as the main factors producing loss of biodiversity (Fahrig 2017).

Deforestation of native forests may result in strong area reductions and increases in isolation and edges of remnant fragments (Groom and Schumaker 1993). These spatial changes in habitats may produce important effects on biodiversity by mean of different ecological mechanisms (Fahrig 2017). For example, effects on genetic and reproductive processes, alterations in species interactions and changes in abiotic conditions, such as increase of air temperature and light, and decrease in soil moisture, have frequently been related to modifications in species richness and composition (Murcia 1995, Chen et al. 1995, Didham and Lawton 1999, Hobbs 2001, Fahrig 2017). For plant species, reductions in fragment size and increases of edge habitats in forest patches usually decrease native species richness (e.g. Laurance et al. 1998, Honnay et al. 1999, Benítez-Malvido and Martínez-Ramos 2003, Guirado et al. 2006) and enhance plant invasion (Brothers and Spingarn 1992, Halpern and Spies 1995, Hobbs 2001, Rojas et al. 2011).

Another important human-caused change in landscapes of forest ecoregions is the installation of exotic forestry plantations (Groom and Schumaker 1993). These plantation ecosystems share some environmental conditions with the original native forests (e.g. shade produced by trees, leaf litter, some cover of understory, etc) and can also support an important number of native species (Brockerhoff et al. 2003, Gómez et al. 2009, Heinrichs et al. 2018). However, depending on the management of plantations, disturbance regime is very different from that of native forests. Especially when plantations are managed using the clear-cutting method, disturbances and strong environmental changes caused by this harvest method may produce detrimental effects on native species richness and enhance invasion of exotic species (Halpern and Spies 1995, Decocq et al. 2004). After plantations have been established, recolonization of native species may also depend on distance to native forests that function as sources of propagules (González-Moreno et al. 2013).

In addition to changes in species richness of native and exotic species, fragmentation and installation of forestry plantations may also produce variations in species composition. A possible pattern to expect in these landscape types is community composition nestedness that results from extinction and colonization of species among plant communities (Honnay et al. 1999, Patterson 1990). A nested pattern occurs when the species composition of areas with lower richness corresponds to a subset of species present in richer areas (Patterson 1990). This ecological pattern may emerge among continuous forests, fragments and plantation areas. For native species, this may occur because shade-tolerant and hygrophilous species might go locally extinct in plantations; therefore, only some of them remain in small fragments and finally all of them remain in continuous forests. Thus, native species composition in plantations would be nested in small fragments, and both of them nested in continuous forests (Honnay et al. 1999). A different pattern may occur through species colonization processes. For example, a continuous forest may be nested in fragments if some native species colonize fragments and no extinction occurs in them. A nested pattern would also be possible to expect for the community of exotic species. In this case, if invasion occurs mainly in plantation areas, then in small fragments, and less in continuous forests, the composition of exotic species in the continuous forests may be a subset of the species found in small fragments, and the composition of small fragments would correspond to a subset of the species found in plantations. Although nestedness patterns have been examined in different native assemblages, this pattern has been less evaluated in exotic plant species (see Higgins et al. 2006 for a review). Current evidence about patterns of species richness and nestedness in fragmented landscapes suggests that native and exotic plant species may respond oppositely to fragmentation and forest replacement. However, few studies have compared patterns of native and exotic species richness and nestedness across a fragmented landscape (e.g. Guirado et al. 2006, Rojas et al. 2011).

Coastal forests of the transition area between Mediterranean and Temperate climates in Chile $\left(35-38^{\circ} \mathrm{S}\right)$ hold a rich and endemic biodiversity (Armesto et al. 1995). However, in this region many native forests have been replaced by other land uses, especially farmlands and commercial forestry plantations of exotic trees such as Pinus radiata $\mathrm{D}$. Don. As a result, native forests remain as small remnant fragments. Few large and continuous forests are still present in the region, most of them corresponding to protected areas (Bustamante and Castor 1998, Echeverría et al. 2007). One of these protected areas is Los Queules National Reserve, a 145 ha protected area, immersed within a large tract of approximately 600 ha of native forest located in the coastal range of Maule Region of Chile. This continuous forest is surrounded by pine plantations and scattered fragments of native forest. Pine plantations are managed using even-age silviculture. Pine plantations are typically harvested using clear-cutting, and stands are established using replanting. After replanting native vegetation is allowed to grow, either by resprouting or dispersal from adjacent native forests (García et al. 2016).

We evaluated the variation of the plant species richness and composition across a landscape dominated by pine plantations, small fragments of native forest and a continuous forest corresponding to Los Queules National Reserve. We compared richness and composition of native and exotic species between these types of landscape units as well as edges and interiors of them. We expect native species richness to be negatively --while exotic species positively-- affected by fragmentation and presence of pine plantations. We also expect these changes in species richness to occur in a nested way across different landscape units and positions. As consequence, we expect changes 
in species composition of both native and exotic species between these landscape units and positions in this forest landscape of this region of Chile.

\section{METHODS}

Study area. The study was conducted in a coastal forest landscape of the transition area between the Mediterranean and Temperate climate regions in Chile $\left(35^{\circ} 59^{\prime} \mathrm{S}, 72^{\circ} 41^{\prime} \mathrm{W}\right)$ (figure 1). The area has between three and five arid months, the mean annual temperature is $12.7^{\circ} \mathrm{C}$ and the mean annual precipitation is $918 \mathrm{~mm}$ (di Castri and Hajek 1976). The landscape is currently composed by native forest fragments of different sizes, and many large stands of pine (Pinus radiata) plantations, the dominant land cover in the landscape. Native forests corresponded to a mixed forest of deciduous and evergreen species, dominated by the deciduous species Nothofagus glauca (Phil.) Krasser and N. obliqua (Mirb.) Oerst. and by evergreen tree species such as Cryptocarya alba (Molina) Looser, Aextoxicon punctatum Ruiz et Pav., and Gevuina avellana Molina. The studied plantation stands substituted the original native forest and were installed shortly after cutting the native forest. Studied plantations corresponded to the first generation after substitution, and were approximately 15 years old at the sampling moment, with 400 individuals per hectare, systematically spaced, and a height of approximately $15 \mathrm{~m}$. Every twenty years, all these plantations are completely harvested by clear-cutting. For this reason, the post-harvest environment is an open habitat, although it is immediately planted with pine seedlings. Based on growth rate of pines, during approximately five years there is very few tree cover (of pines) in the plantations. The height of the plantation reaches the height of the native forest approximately at 10-12 years.

Sampling design. During spring and summer of 20062007, $60100 \mathrm{~m}^{2}(10 \times 10 \mathrm{~m})$ plots were installed in three types of landscape unit (continuous forest, fragments and plantation). A continuous forest corresponded to an area of native forest with a continuous cover of native trees and a surface larger than $100 \mathrm{ha}$, which was the minimal area used by Laurance et al. (1998) to define a non-fragmented and continuous forest. A fragment corresponded to an area of forest with a continuous cover of native trees and a surface smaller than 100 ha. However, in this study we used only small fragments (hereafter fragments), all of them smaller than 5 ha to extreme differences in size with continuous forests. We found one continuous forest (600 ha); part of this forest fall within "Los Queules" National Re-

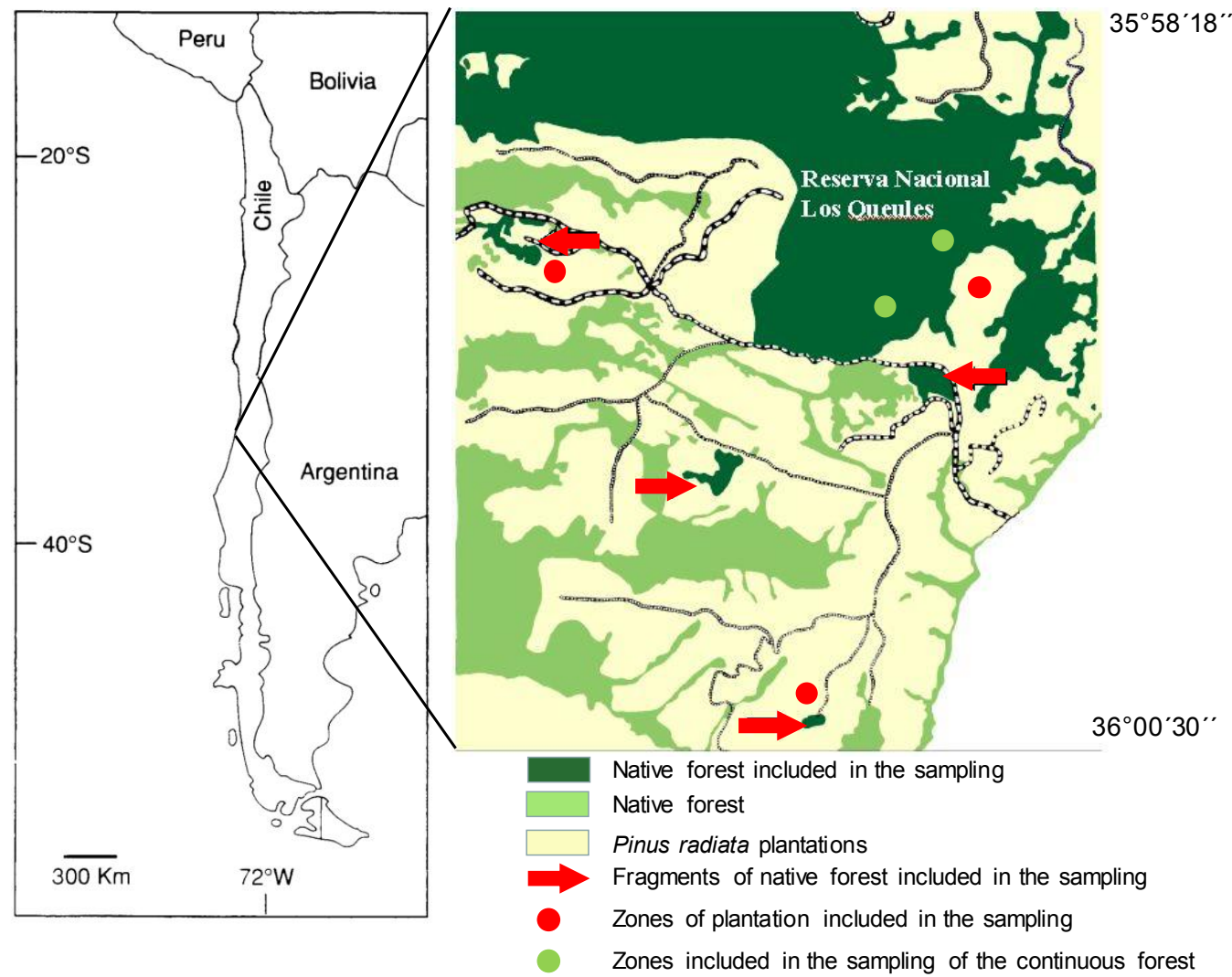

Figure 1. Location of the study area. Sampled zones of the continuous forest, fragments and pine plantations are shown.

Ubicación del área de estudio. Se muestran el bosque continuo, fragmentos y plantaciones de Pinus radiata. 
serve (145 ha). We used four fragments in the study and corresponded to nearby patches of the same native forest. Areas of fragments varied between 0.8 and 3.4 ha, approximately. Distance between fragments and among these and the continuous forest varied between 0.2 and $2.7 \mathrm{~km}$ (figure 1). All the fragments had similar habitat conditions since all of them were on flat areas or south and southwest-facing gentle slopes. The studied zones of the continuous forest and plantation were also flat areas or south-facing slopes.

To quantify plant communities on each landscape unit, we located ten plots in the edges and ten plots in the interior (hereafter positions). Plots at edges were located just at the beginning of the tree cover of each unit. The edges of fragments and continuous forest were located adjacent to plantations. The edges of plantation were located adjacent to fragments and continuous forest (figure 1). The plots in the interior were located approximately $40 \mathrm{~m}$ into fragments, a distance approximately twice the height of trees in fragments. In the continuous forest and plantation, interior plots were located $100 \mathrm{~m}$ from the closest edge. Because of the size of the small fragments selected for this study, the maximum distance between interior sites and edges in them could not be larger than $40 \mathrm{~m}$. Instead, in the continuous forest and plantation we preferred to use larger distance $(100 \mathrm{~m})$ between interior sites and edges to avoid any environmental influence of edges in interior sites (Laurance et al. 1998). This different distance between edges and interior positions in fragments regarding the other landscape units implies that possible observed edge effects (contrasting results between edges and interior positions) should be carefully interpreted, considering separately edge effects between landscape units.

We sampled the continuous forest in two zones per position $200 \mathrm{~m}$ apart (figure 1), each with five plots (five plots at the edge and five at the interior). In fragments, we sampled two plots in each position in two fragments, and three plots per position in the other two fragments (figure 1). Because the plantation was compared to the continuous forest as well as fragments, we sampled the plantation (edges and interior) in three zones: one zone adjacent to the continuous forest and the other two zones adjacent to each of two different fragments (figure 1). In the zone adjacent to the continuous forest, we installed five plots at the edge and five plots in the interior. In one zone adjacent to one fragment we installed two plots at the edge and two plots at the interior of the plantation. The third zone sampled in the plantation was located adjacent to another fragment, with three plots at the edge and three plots at the interior. All plots in each position in all landscape units were separated by $10 \mathrm{~m}$ along a transect parallel to the nearest edge. The fact of separating the sampling of the plantation in three zones, the continuous forest in two zones and fragments in four small parts (figure 1) allowed us to reduce the level of pseudoreplication. However, plots sampled within each zone and within a specific fragment were effectively pseudoreplicates, which is a limitation of this study.
Data analyses. All analyses were carried out separately for the total of vascular plants, native species and exotic species. Nomenclature and biogeographic origin of species were established according to Rodríguez et al. (2018). Differences in species richness between landscape units and positions were evaluated by a two-way analysis of variance (ANOVA) as data of richness satisfied normality of distribution. Richness of exotic species was square root transformed for normality of data. We considered the landscape unit (continuous forest, fragments and plantation) and the position (edge and interior) as factors. Replicates were ten plots per combination of landscape unit and position, and 60 in total. We performed Tukey tests to examine specific comparisons.

We also assessed the nestedness between landscape locations (landscape units and positions). To do this, we evaluated the order and disorder of the distribution pattern of species through the landscape by Temperature Analyses (sensu Atmar and Patterson 1995) for each group of species (total, native, exotic). The temperature analysis allows to establish whether there is some general pattern among locations in the landscape, either nestedness or checkboard pattern (Atmar and Patterson 1995). Temperature analyses were carried out according to Nestedness Temperature Calculator program (Atmar and Patterson 1995), in which an observed Temperature Value $(T)$ is obtained and compared to a randomly determined $T$ value by a Monte Carlo simulation process. Values of $T$ significantly lower than expected by chance indicate nestedness, and $T$ values significantly higher than expected by chance indicate a checkboard pattern (Atmar and Patterson 1995).

Finally, differences in species composition between landscape units and positions were assessed by cluster analyses pooling all species from the 10 plots installed per each combination of landscape unit and position. We used the Jaccard's coefficient for comparison between each combination of landscape unit and position. This index does not account for abundance of species, and thus, probably these values overestimate the similarity between landscape units and positions. A value of 1 indicates equal composition and a value of zero indicates completely different composition. Cluster analyses were performed by an Unweighted Pair Group Method using Arithmetic averages (UPGMA) procedure. We determined critical values of similarity lower and higher than expected by chance. These values were obtained by a Monte Carlo simulation process from a randomly calculated matrix of similarity. We allowed a completely random number of species per location and number of location per species for the random process. We produced 1,000 random values of Jaccard's coefficient for each comparison and 15,000 in total from all pairs of comparisons. From these 15,000 values, we obtained the $5^{\text {th }}$ and the $95^{\text {th }}$ percentiles for determining the significant value below and above which clusters had significantly lower and higher values than expected by chance, respectively. 


\section{RESULTS}

Flora of native and exotic species. We found 95 species of vascular plants corresponding to 88 genera and 50 families. Eighty-nine species were Magnoliophyta, one species was Pinophyta and five species were Pteridophyta. The flora is composed mostly of herbs and less by lianas, and $79(83.2 \%)$ species were natives while $16(16.8 \%)$ were exotics (table 1). Exotic species were mainly herbs, while natives were mainly and equally represented by shrubs and trees (table 1).

Patterns of species richness. Pooling the total number of species from the ten plots per combination of landscape unit and position, total species richness of vascular plants

Table 1. Percentage (\%) of species belonging to each biogeographic origin per growth form.

Porcentaje (\%) de especies pertenecientes a cada origen biogeográfico por forma de vida.

\begin{tabular}{lcccc}
\hline Origin & Trees & Shrubs & Herbs & Lianas \\
\hline Total & 22.1 & 24.2 & 43.2 & 10.5 \\
Exotics & 6.3 & 18.7 & 75.0 & 0.0 \\
Natives & 25.3 & 25.3 & 36.7 & 12.7 \\
\hline
\end{tabular}

was higher at the edges of fragments and lower at the interior of the plantation (table 2). In native species, total species richness was higher in the edge of the continuous forest and the lowest value was observed in the interior of the plantation (table 2). Total exotic species richness was higher at the edge of the plantation and the lowest value occurred in the interior of the continuous forest where no exotic species was observed (table 2).

Regarding richness at a plot level, species richness of all vascular plants significantly varied between landscape units nonetheless not between positions, and the statistical interaction between these factors was not significant (table 3, figure 2A). Specifically, richness of vascular plants was significantly higher in the continuous forest and fragments than in the plantation, with no significant difference between the first two landscape units (figure 2A). Richness of native species per plot significantly differed between landscape units though not between positions, and the statistical interaction between these factors was not statistically significant (table 3 ). In this case, species richness was significantly higher in the continuous forest and fragments than in the plantation, with no significant difference between the first two landscape units (figure 2B). Richness of exotic species per plot significantly differed between landscape units and positions, and the statistical interaction between these factors was significant (table 3). We observed significantly higher exotic species richness in the plantation than in the continuous forest, both at edges

Table 2. Total species richness (pooling all plots) for each species type per landscape unit and position. (C: continuous forest, F: fragments, P: plantation, E: edge, I: interior).

Riqueza total de especies (combinando todas las parcelas) por cada tipo de especies y por posición y unidad de paisaje (C: bosque continuo, F: fragmentos, P: plantación, E: borde, I: interior).

\begin{tabular}{|c|c|c|c|c|c|c|c|c|c|c|c|c|}
\hline \multirow[t]{2}{*}{ Variable } & \multicolumn{2}{|c|}{$\mathrm{CE}$} & \multicolumn{2}{|c|}{$\mathrm{CI}$} & \multicolumn{2}{|c|}{$\mathrm{FE}$} & \multicolumn{2}{|c|}{ FI } & \multicolumn{2}{|c|}{$\mathrm{PE}$} & \multicolumn{2}{|c|}{ PI } \\
\hline & $\mathrm{N}^{\circ}$ & $\%$ & $\mathrm{~N}^{\circ}$ & $\%$ & $\mathrm{~N}^{\circ}$ & $\%$ & $\mathrm{~N}^{\circ}$ & $\%$ & $\mathrm{~N}^{\circ}$ & $\%$ & $\mathrm{~N}^{\circ}$ & $\%$ \\
\hline All vascular plants & 56 & - & 41 & - & 57 & - & 44 & - & 48 & - & 36 & - \\
\hline Natives & 52 & 92.9 & 41 & 100 & 47 & 82.5 & 42 & 95.5 & 35 & 72.9 & 27 & 75.0 \\
\hline Exotics & 4 & 7.1 & 0 & 0.0 & 10 & 17.5 & 2 & 4.5 & 13 & 27.1 & 9 & 25.0 \\
\hline
\end{tabular}

Table 3. Results from two-way ANOVAs for the effect of landscape unit, position and its interaction on total richness, exotic species richness and native species richness. Richness of exotic species was square root transformed for normality of data.

Resultados de ANOVA de dos vías para los efectos de la unidad de paisaje, posición y su interacción sobre la riqueza total de especies, riqueza de especies exóticas y de especies nativas. Riqueza de especies exóticas fue transformada para normalidad de datos con la raíz cuadrada.

\begin{tabular}{lcccccc}
\hline Richness & \multicolumn{2}{c}{ Landscape unit } & \multicolumn{2}{c}{ Position } & \multicolumn{2}{c}{ Unit x Position } \\
\cline { 2 - 7 } & $\mathrm{F}_{(2,54)}$ & $P$ & $\mathrm{~F}_{(1,54)}$ & $P$ & $\mathrm{~F}_{(2,54)}$ & $P$ \\
\hline All vascular plants & 14.76 & $<0.001$ & 2.36 & 0.131 & 0.11 & 0.891 \\
Native & 33.04 & $<0.001$ & 0.25 & 0.622 & 0.12 & 0.880 \\
Exotic & 19.54 & $<0.001$ & 28.96 & $<0.001$ & 2.73 & 0.050 \\
\hline
\end{tabular}




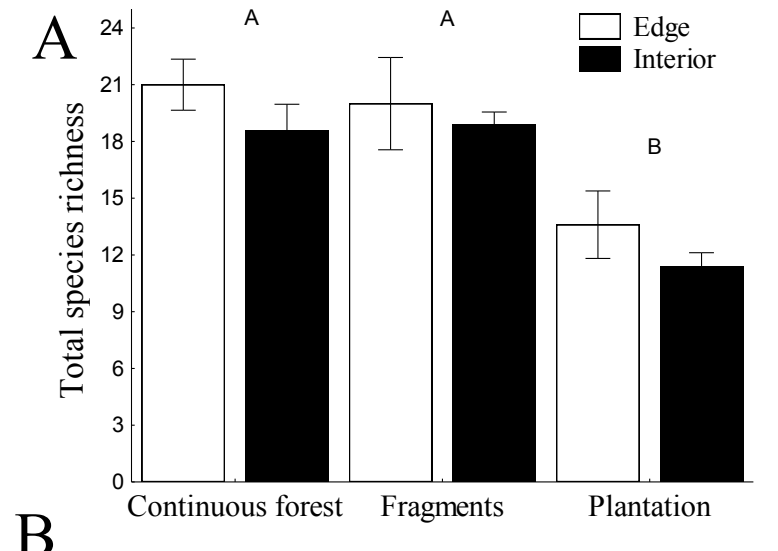

B
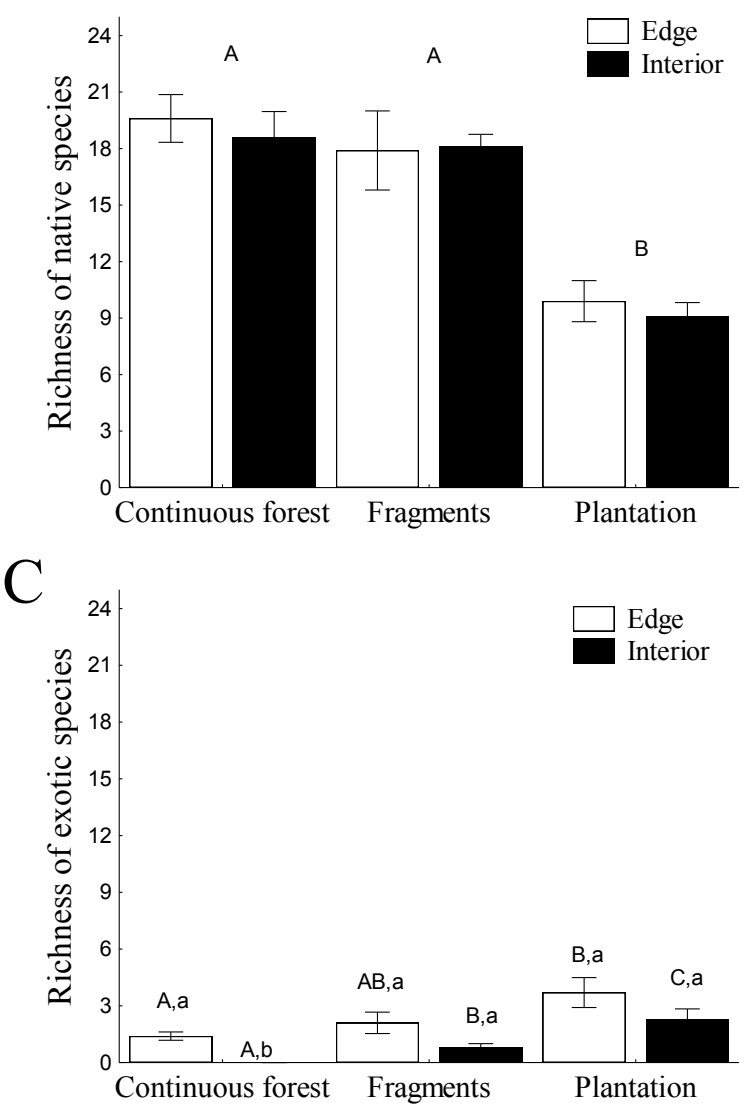

Figure 2. Species richness of all vascular plants (A), native species (B) and exotic species (C) perposition (interior and edge) and landscape unit (continuous forest, fragments, and plantation). Different uppercase letters indicate significant differences (Tukey, $P<0.05$ ) between landscape units for a single position, and different lowercase letters indicate significant differences (Tukey, $P<$ 0.05 ) between positions for a single landscape unit.

Riqueza de especies total de plantas vasculares (A), nativas (B) and exóticas (C) por posición (interior y borde) y unidad de paisaje (bosque continuo, fragmentos, and plantación). Diferentes letras mayúsculas indican diferencias significativas (Tukey, $P<0,05$ ) entre unidades de paisaje, y diferentes letras minúsculas indican diferencias significativas (Tukey, $P<0,05$ ) entre posiciones. and interiors. Likewise, species exotic richness was significantly more important in the plantation than in fragments in interior positions nevertheless not in edges (figure 2C). Fragments had significantly larger exotic species richness than that present in the continuous forest in interior positions, though not at edges (figure $2 \mathrm{C}$ ). In addition, only in the continuous forest there was a significant difference between positions, being exotic species richness at edges significantly higher than in the interior (figure 2C). In the other landscape units, exotic species richness was also superior at edges than in interiors, although without significant statistical differences (figure 2C).

Nestedness pattern. Regarding all vascular plants, there was no a significant nestedness pattern (table 4). By contrast, native species were significantly nested across landscape units and positions considered in this study (table 4). This indicates that positions and landscape units with lower native species richness were composed of a subset of species present in the richer ones (see table 2). In this case, this pattern was mainly produced by several species which were present in both fragments and continuous forest, although not in the plantation (and not the inverse), such as Aextoxicon punctatum Ruiz et Pav., Chusquea quila Kunth, Citronella mucronata (Ruiz et Pav.) D. Don, Viola portalesia Gay, Raphitamnus spinosus (Juss.) Moldenke, Greigia sphacelata (Ruiz et Pav.) Regel, Lomatia dentata (Ruiz et Pav.) R. Br., Senna stipulacea (Aiton) H.S. Irwin et Barneby, Lardizabala biternata Ruiz et Pav. (table 5). Similarly, the nestedness in native species was generated by some native species which were present in edges, though not in interior sites (and not the inverse). For example, in the continuous forest, this occurred in Adiantum chilense Kaulf. Lepechinia chilensis (Molina) R. Morales, Lithrea caustica (Molina) Hook. et Arn., Muehlenbeckia hastulata (Sm.) I.M. Johnst., Nassella gigantea (Steud.) Muñoz-Schick, Ribes punctatum Ruiz et Pav. In fragments, this occurred in Chiropetalum tricuspidatum (Lam.) A. Juss., Greigia sphacelata (Ruiz et Pav.) Regel, Senna stipulacea (Aiton) H.S. Irwin et Barneby, Uncinia macloviana Gaudich.

Table 4. Nestedness (Temperature value, $T$ ) among locations in the landscape for each species type. Values of observed $T$ and $T$ under a null model (mean \pm 1 S.D.) from Monte Carlo simulation are shown.

Anidamiento (Valor de Temperatura, $T$ ) entre posiciones en el paisaje por cada tipo de especie. Se muestran valores observados de $T$ y de $T$ usando un modelo nulo (media \pm 1 D.S.) a través de una simulación tipo Monte Carlo.

\begin{tabular}{lccc}
\hline Species group & Observed $T$ & Null $T$ & $P$ \\
\hline All vascular plants & 47.41 & $50.50 \pm 4.72$ & 0.257 \\
Natives & 40.70 & $50.43 \pm 5.10$ & 0.028 \\
Exotics & 11.22 & $38.30 \pm 9.35$ & 0.002 \\
\hline
\end{tabular}


On the other hand, exotic species also showed a significantly nested distribution (table 4). This pattern was mainly produced by several exotic species which were present in the plantation, nonetheless not in fragments or continuous forest (and not the inverse) (e.g. Rumex acetosella L., Holcus lanatus L., Prunella vulgaris L.), and by other exotic species present in the plantation and fragments, though not in the continuous forest (and not the inverse) (e.g. Cynosurus echinatus L., Rosa rubiginosa L.) (table 5). Correspondingly, this pattern was generated by exotic species which were present in edges, nevertheless not in interior sites (and not the inverse), either in fragments and continuous forest (e.g. Rubus ulmifolius Schott, Agrostis capillaris L.), or in the plantation (e.g. C. echinatus, R. acetosella, H. lanatus) (table 5).

Table 5. Origin (N: native, E: exotic), climatic region of distribution of native species in Chile (CR) (T: temperate, M: Mediterranean), Life form (A: tree, N: shrub, H: herb, L: liana), and frequency ( $\%$ of plots with presence) of species growing in each landscape unit and position (C: continuous forest, F: fragment, P: plantation, E: edge, I: interior). Only exotic and native species with mean frequency $>$ $10 \%$ are shown. Values for Pinus radiata correspond to naturally growing individuals (naturalized).

Origen (N: nativo, E: exótico), región climática de distribución de las especies nativas en Chile (CR) (T: templada, M: mediterránea), forma de vida (A: árbol, N: arbusto, H: hierba, L: liana), y frecuencia (\% de parcelas) de las especies en cada unidad y posición de paisaje (C: bosque continuo, F: fragmento, P: plantación, E: borde, I: interior). Se muestran solo especies nativas o exóticas con frecuencia $>10 \%$. Valores para Pinus radiata corresponden a individuos naturalizados.

\begin{tabular}{|c|c|c|c|c|c|c|c|c|c|}
\hline Species & Origin & $\mathrm{CR}$ & LF & $\mathrm{CE}$ & $\mathrm{CI}$ & $\mathrm{FE}$ & FI & PE & PI \\
\hline Agrostis capillaris $\mathrm{L}$. & E & & $\mathrm{H}$ & 10 & 0 & 30 & 0 & 30 & 10 \\
\hline Cynosurus echinatus L. & E & & $\mathrm{H}$ & 0 & 0 & 20 & 0 & 20 & 0 \\
\hline Digitalis purpurea $\mathrm{L}$. & E & & $\mathrm{H}$ & 10 & 0 & 0 & 0 & 0 & 0 \\
\hline Gastridium ventricosum (Gouan) Schinz et Thell. & $\mathrm{E}$ & & $\mathrm{H}$ & 0 & 0 & 10 & 0 & 10 & 0 \\
\hline Holcus lanatus $\mathrm{L}$. & $\mathrm{E}$ & & $\mathrm{H}$ & 0 & 0 & 0 & 0 & 10 & 0 \\
\hline Hypericum perforatum $\mathrm{L}$. & $\mathrm{E}$ & & $\mathrm{H}$ & 0 & 0 & 10 & 0 & 20 & 0 \\
\hline Hypochaeris radicata $\mathrm{L}$. & E & & $\mathrm{H}$ & 0 & 0 & 0 & 0 & 0 & 10 \\
\hline Lactuca virosa $\mathrm{L}$. & $\mathrm{E}$ & & $\mathrm{H}$ & 0 & 0 & 10 & 0 & 30 & 20 \\
\hline Pinus radiata D. Don & E & & $\mathrm{A}$ & 0 & 0 & 40 & 20 & 30 & 10 \\
\hline Plantago lanceolata $\mathrm{L}$. & E & & $\mathrm{H}$ & 0 & 0 & 20 & 0 & 20 & 20 \\
\hline Prunella vulgaris $\mathrm{L}$. & $\mathrm{E}$ & & $\mathrm{H}$ & 0 & 0 & 0 & 0 & 10 & 0 \\
\hline Rosa rubiginosa $\mathrm{L}$. & $\mathrm{E}$ & & $\mathrm{N}$ & 0 & 0 & 10 & 0 & 40 & 40 \\
\hline Rubus ulmifolius Schott & E & & $\mathrm{N}$ & 40 & 0 & 10 & 0 & 50 & 60 \\
\hline Rumex acetosella $\mathrm{L}$. & E & & $\mathrm{H}$ & 0 & 0 & 0 & 0 & 10 & 0 \\
\hline Sanguisorba minor Scop. & $\mathrm{E}$ & & $\mathrm{H}$ & 0 & 0 & 0 & 0 & 0 & 10 \\
\hline Teline monspessulana (L.) K. Koch & $\mathrm{E}$ & & $\mathrm{N}$ & 80 & 0 & 50 & 60 & 90 & 50 \\
\hline Adiantum chilense Kaulf. & $\mathrm{N}$ & MT & $\mathrm{H}$ & 40 & 0 & 10 & 40 & 10 & 0 \\
\hline Aextoxicon punctatum Ruiz et Pav. & $\mathrm{N}$ & MT & A & 100 & 100 & 40 & 40 & 0 & 0 \\
\hline Aristotelia chilensis (Molina) Stuntz & $\mathrm{N}$ & $\mathrm{T}$ & A & 90 & 50 & 100 & 90 & 100 & 100 \\
\hline Azara integrifolia Ruiz et Pav. & $\mathrm{N}$ & $\mathrm{T}$ & $\mathrm{A}$ & 50 & 40 & 70 & 80 & 20 & 50 \\
\hline Blechnum hastatum Kaulf. & $\mathrm{N}$ & $\mathrm{T}$ & $\mathrm{H}$ & 80 & 100 & 80 & 90 & 50 & 10 \\
\hline Bomarea salsilla (L.) Herb. & $\mathrm{N}$ & MT & $\mathrm{H}$ & 10 & 70 & 20 & 80 & 0 & 10 \\
\hline Chiropetalum tricuspidatum (Lam.) A. Juss. & $\mathrm{N}$ & $\mathrm{T}$ & $\mathrm{H}$ & 50 & 40 & 30 & 0 & 0 & 0 \\
\hline Chusquea quila Kunth & $\mathrm{N}$ & $\mathrm{T}$ & $\mathrm{N}$ & 40 & 50 & 10 & 30 & 0 & 0 \\
\hline Cissus striata Ruiz et Pav. & $\mathrm{N}$ & M & $\mathrm{L}$ & 90 & 60 & 60 & 50 & 50 & 70 \\
\hline Citronella mucronata (Ruiz et Pav.) D. Don & $\mathrm{N}$ & M & A & 10 & 30 & 30 & 20 & 0 & 0 \\
\hline Cryptocarya alba (Molina) Looser & $\mathrm{N}$ & M & A & 90 & 100 & 80 & 70 & 80 & 70 \\
\hline
\end{tabular}


Table 5 Continued

\begin{tabular}{|c|c|c|c|c|c|c|c|c|c|}
\hline Gevuina avellana Molina & $\mathrm{N}$ & $\mathrm{T}$ & A & 50 & 100 & 70 & 100 & 20 & 30 \\
\hline Greigia sphacelata (Ruiz et Pav.) Regel & $\mathrm{N}$ & $\mathrm{T}$ & $\mathrm{N}$ & 50 & 90 & 20 & 0 & 0 & 0 \\
\hline Herreria stellata Ruiz et Pav. & $\mathrm{N}$ & $\mathrm{T}$ & $\mathrm{L}$ & 30 & 50 & 50 & 40 & 40 & 0 \\
\hline Lapageria rosea Ruiz et Pav. & $\mathrm{N}$ & $\mathrm{T}$ & $\mathrm{L}$ & 70 & 100 & 40 & 80 & 20 & 0 \\
\hline Lardizabala biternata Ruiz et Pav. & $\mathrm{N}$ & MT & $\mathrm{L}$ & 70 & 60 & 10 & 20 & 10 & 0 \\
\hline Laurelia sempervirens (Ruiz et Pav.) Tul. & $\mathrm{N}$ & $\mathrm{T}$ & A & 50 & 10 & 20 & 20 & 20 & 20 \\
\hline Lepechinia chilensis (Molina) R. Morales & $\mathrm{N}$ & $\mathrm{T}$ & $\mathrm{N}$ & 20 & 0 & 20 & 10 & 20 & 50 \\
\hline Lithrea caustica (Molina) Hook. et Arn. & $\mathrm{N}$ & M & A & 10 & 0 & 80 & 80 & 0 & 0 \\
\hline Lomatia dentata (Ruiz et Pav.) R. Br. & $\mathrm{N}$ & $\mathrm{T}$ & $\mathrm{A}$ & 80 & 100 & 50 & 40 & 0 & 10 \\
\hline Luma apiculata (DC.) Burret & $\mathrm{N}$ & $\mathrm{T}$ & A & 100 & 70 & 100 & 70 & 80 & 80 \\
\hline Luzuriaga radicans Ruiz et Pav. & $\mathrm{N}$ & $\mathrm{T}$ & $\mathrm{L}$ & 70 & 80 & 0 & 0 & 0 & 0 \\
\hline Muehlenbeckia hastulata (Sm.) I.M. Johnst. & $\mathrm{N}$ & M & $\mathrm{N}$ & 30 & 0 & 0 & 0 & 20 & 100 \\
\hline Nassella gigantea (Steud.) Muñoz-Schick & $\mathrm{N}$ & $\mathrm{T}$ & $\mathrm{H}$ & 30 & 0 & 60 & 50 & 40 & 40 \\
\hline Nothofagus glauca (Phil.) Krasser & $\mathrm{N}$ & M & A & 0 & 0 & 40 & 60 & 0 & 0 \\
\hline Nothofagus obliqua (Mirb.) Oerst. & $\mathrm{N}$ & MT & A & 70 & 40 & 100 & 90 & 60 & 30 \\
\hline Persea lingue (Ruiz et Pav.) Nees & $\mathrm{N}$ & MT & A & 40 & 90 & 80 & 70 & 20 & 40 \\
\hline Peumus boldus Molina & $\mathrm{N}$ & M & A & 0 & 0 & 40 & 30 & 40 & 40 \\
\hline Proustia pyrifolia DC. & $\mathrm{N}$ & M & $\mathrm{L}$ & 10 & 10 & 30 & 10 & 20 & 10 \\
\hline Quillaja saponaria Molina & $\mathrm{N}$ & M & A & 0 & 0 & 40 & 20 & 20 & 10 \\
\hline Raphitamnus spinosus (Juss.) Moldenke & $\mathrm{N}$ & MT & $\mathrm{N}$ & 70 & 20 & 20 & 30 & 0 & 0 \\
\hline Ribes punctatum Ruiz et Pav. & $\mathrm{N}$ & MT & $\mathrm{N}$ & 10 & 0 & 50 & 40 & 50 & 30 \\
\hline Senna stipulacea (Aiton) H.S. Irwin et Barneby & $\mathrm{N}$ & $\mathrm{T}$ & $\mathrm{N}$ & 40 & 80 & 20 & 0 & 0 & 0 \\
\hline Ugni molinae Turcz. & $\mathrm{N}$ & $\mathrm{T}$ & $\mathrm{N}$ & 20 & 10 & 40 & 60 & 20 & 10 \\
\hline Uncinia macloviana Gaudich. & $\mathrm{N}$ & $\mathrm{T}$ & $\mathrm{H}$ & 90 & 20 & 20 & 0 & 0 & 10 \\
\hline Viola portalesia Gay & $\mathrm{N}$ & $\mathrm{T}$ & $\mathrm{H}$ & 10 & 30 & 50 & 80 & 0 & 0 \\
\hline
\end{tabular}

Patterns of species similarities. Regarding all vascular plants as well as native species, no similarity value was lower than expected by chance (figure 3 ). Interior sites and edges presented higher similarity values than expected by chance in each landscape unit (figure 3), and fragments were significantly more similar to the continuous forest than expected by chance (figure 3). In turn, similarity between the plantation and any other landscape unit was not lower or higher than expected by chance (figure 3 ). In exotic species, we found that similarity between the interior of the continuous forest and the other combinations of landscape unit and position were lower than expected by chance (figure 3). In addition, edges and interiors of the plantation and edges of fragments were significantly more similar than expected by chance (figure 3 ).

\section{DISCUSSION}

Expansion of exotic forestry plantations and fragmentation of native forests have produced important effects on plant communities of our study area. These effects have been different for native and exotic species. Regarding native species, our results suggest that, in contrast to our predictions, reductions of area of the native forest (from continuous forest to small fragments) and presence of edges had no important impact on the native species richness at a plot scale. These results contrast to many other studies documenting that fragmentation negatively affects native species diversity (e.g. Laurance et al. 1998, Honnay et al. 1999, Hobbs 2001, Benítez-Malvido and MartínezRamos 2003, Guirado et al. 2006, Echeverría et al. 2007) at a patch scale (sensu Fahrig 2017). Habitat fragmentation frequently produces higher radiation and lower soil moisture in edges and small fragments compared to interior sites and continuous forests (Chen et al. 1995, Murcia 1995, Didham and Lawton 1999). However, in our study area, when plantations reach tree cover and height similar to that of the native forest (approximately 10 years after cutting and planting), environmental changes in edges and small fragments may be ameliorated, which could allow 

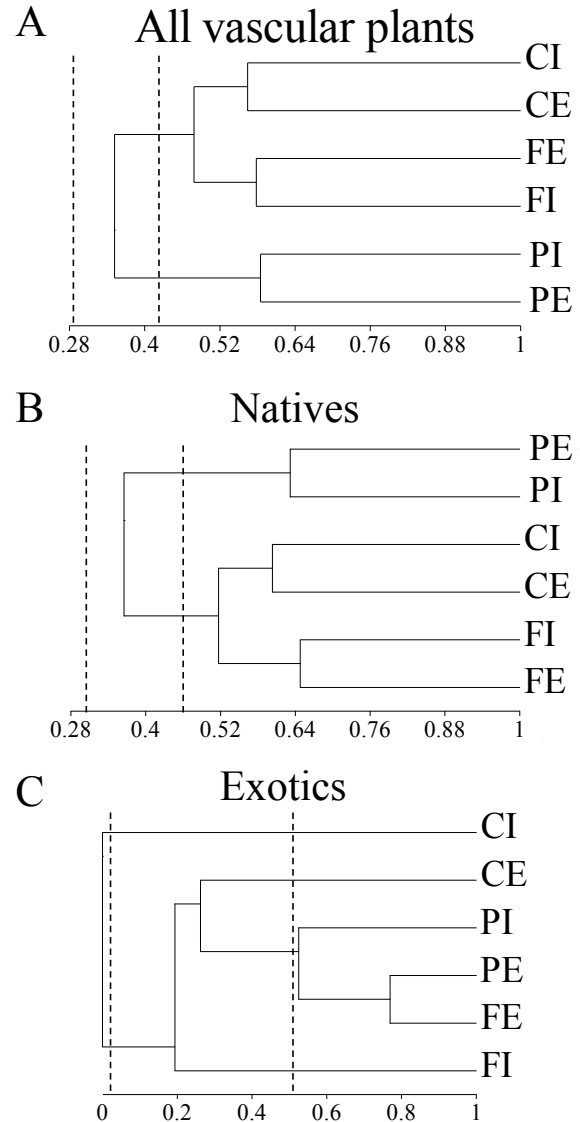

Figure 3. Species similarities for all vascular plants (A), native species (B) and exotic species (C) among locations in the landscape (CI: continuous forest interior, $\mathrm{CE}$ : continuous forest edge, FI: fragments interior, FE: fragments edge, PI: interior of pine plantation, PE: edge of pine plantation) using Jaccard's coefficient and a UPGMA procedure. Dashed lines indicate level of similarity below (left line) and above (right line) which cluster are significantly more different and more similar than expected by chance respectively.

Similitud de especies para todas las plantas vasculares (A), especies nativas (B) y especies exóticas (C) entre ubicaciones en el paisaje (CI: interior de bosque continuo, CE: borde de bosque continuo, FI: interior de fragmentos, FE: borde de fragmento, PI: interior of plantación de pino, PE: borde de plantación de pino) usando el coeficiente de Jaccard y procedimiento UPGMA. Líneas segmentadas indican el nivel de similitud bajo y sobre el cual las agrupaciones son significativamente más diferentes y más similares que lo esperado por azar respectivamente.

the survival of native species present in adjacent edges of fragments and continuous forest (e.g. Vandermeer and Carvajal 2001). Furthermore, certain habitat continuity produced by adult plantations could reduce any isolation effect on native species communities of fragments (Fahrig 2017). Thus, the presence of forestry plantations surrounding fragments may explain the absence of significant fragmentation effects on native species richness in this area. Instead, in other cases, for example Echeverría et al. (2007) and Rojas et al. (2011) in the south of Chile, frag- ments were surrounded by agricultural crops, a radically different environment from native forest fragments, which could have produced strong edge and isolation effects and thus explained the negative effects of fragmentation on native species richness observed in these studies.

Nevertheless, edges and interior sites in fragments as well as in the continuous forest were not identical in native species composition. Although native species similarity between edges and interior sites was higher than expected by chance both in fragments and continuous forest, we observed values only around $\sim 60 \%$. This is consistent with the nestedness produced by the presence of several species in edges, however not in interior sites in both landscape units, which could be related to typical increases in radiation and temperature in edges compared to interior sites (Chen et al. 1995, Murcia 1995).

Regarding native species, patterns observed in the continuous forest were quite similar to those observed in fragments, despite different distance edge-interior between these two landscape units. Moreover, native species richness at a plot scale and species composition of interior sites did not significantly differ between fragments and continuous forest. This suggests that, at least in terms of native species, areas $40 \mathrm{~m}$ into the interior of native forests are still behaving as interior habitats.

On the other hand, native species richness in edges and interior sites of fragments and continuous forest were significantly larger than edges and interiors of the pine plantation. This is consistent with the nested pattern observed in native species, mainly produced by several species present in fragments and continuous forest, however not in the pine plantation. As consequence, native species composition in the plantation was not more similar than expected by chance to edges or interiors of fragments and continuous forest. This was probably triggered by many native species which were not able to resprout or regenerate from seeds after pine plantations were installed. These results suggest that plantations cannot hold native plant assemblages similar to those held by the native forests in this area, which has also been observed in other studies (Halpern and Spies 1995, Heinrichs et al. 2018). Decreased native species richness in the plantation may be related to direct effects of disturbance when native forests were clear-cut (Brockerhoff et al. 2003), or environmental changes after cutting, that inhibit their recolonization (Decoq et al. 2004). However, 15 years after cutting and planting (age of studied plantations), native species richness in the plantation reached near half of the richness observed in native forests, indicating that the environment of a pine plantation is not completely detrimental for growing native species. In fact, some studies report that Pinus radiata plantations may be recolonized by many native species after planting even reaching, in older plantations, levels of species richness similar to those reached in adjacent native forests (Brockerhoff et al. 2003). A possible cause of this important native diversity within plantations could be 
the fact that these plantations directly substituted the original native forest and were installed shortly after cutting it. Hence, probably some native species could resprout or regenerate from seed banks and thus recolonize these plantations. Additionally, native species richness and composition did not differ between interior sites and edges in the plantation, which could be produced by efficient seed dispersal (García et al. 2016), at least up to $100 \mathrm{~m}$ into the interior. However, García et al. (2016) suggested that beyond $160 \mathrm{~m}$ very few seeds may access into plantation stands in this same locality, and probably beyond $160 \mathrm{~m}$ native diversity might decrease. On the other hand, despite native diversity can grow within plantations, clear-cutting system applied in them may limit long-term conservation of the native flora in them (Heinrichs et al. 2018). Survival levels of individuals of native species after applying clear-cutting in pine plantations are unknown. It is also unknown how long and how many rotations of pine plantations, using this management system, native species may survive, resprout or regenerate from seed banks.

Richness of exotic species was enhanced by fragmentation. We found higher exotic richness in small fragments than in the continuous forest in interior sites, but not in edges. Furthermore, exotic richness was higher in edges than interiors in the continuous forest, though not in fragments. These patterns suggest that, in terms of plant invasion, interior sites are behaving more similar to edges in fragments than in the continuous forest. This could be related to the shorter distance edge-interior in fragments than in the continuous forest. Furthermore, interior sites and edges of both fragments and continuous forest presented less exotic richness than that presented by plantations. This pattern is consistent with the nested pattern observed in exotic species, in which, many exotic species were present in the plantation, though not in fragments and continuous forest. As a result of this species distribution, exotic species composition in edges of fragments was more similar than expected by chance to exotic composition in edges and interior of the plantation. These results indicate that reduction of area and presence of edges in native forests, as well as replacement of the native forest by pine plantations, have facilitated the invasion of exotic plants. Furthermore, our results suggest that exotic species invade from the plantation toward the native forest, first along edges, and then the interior of fragments, although only two species have been able to invade interior sites of fragments, and no exotic species the interior of the continuous forest. All these results about exotic species are consistent with previous studies. Invasion of exotic plants has generally been observed to be higher within small fragments and edges compared to larger fragments and interior sites (e.g. Brothers and Spingarn 1992, Hobbs and Huenneke 1992, Richardson et al. 1994, Hobbs 2001, Rojas et al. 2011), probably due to resource release, especially light (Chen et al. 1995). On the other hand, positive effects on exotic invasion produced by logging and clear-cutting in plantations have been a widely documented pattern (Halpern and Spies 1995, Silveri et al. 2001, Becerra and Simonetti 2013). Especially when plantations are open habitats (for 7-10 years after cutting and planting), increased radiation (Chen et al. 1995) and nutrient release (Hobbs and Huenneke 1992) may enhance plant invasion (Silveri et al. 2003, Decocq et al. 2004). Although we did not use edges next to roads, roads probably were the main way for exotic species to immigrate into our study area, firstly into the plantation (Heinrichs et al. 2018).

Because this landscape is mainly composed of native species, patterns of richness and similarity of the total plant community followed the patterns observed in native species. Nevertheless, total community did not show nestedness among landscape units and positions, mainly because native and exotic species showed relatively different nestedness patterns. Our results also suggest that native and exotic species respond oppositely to the presence of pine plantations. Instead, native and exotic species respond differently but not oppositely to fragmentation as natives were not affected while exotics were positively influenced by it. Therefore, these results contrast with studies carried out in other temperate forest of south of Chile (Rojas et al. 2011) and Europe (Guirado et al. 2006), where native and exotic species richness responds oppositely to fragmentation. This suggests that exotic species were more sensitive than native species to the same environmental modification of the native forest.

Our study had different limitations and hence our inferences should be considered with caution. The use of only one large continuous forest impedes us to generalize our results for other continuous forests of the region. Thus, further research is necessary to examine if our findings also occur in other large fragments of native forest. On the other hand, although pine plantation and continuous forest were sampled in different zones within the study area, reduced number of zones and fragments, also constrains our potential to generalize our results. However, very few studies have examined the variability of plant communities across landscapes dominated by pine plantations, native forest fragments and more continuous native forests in this region of Chile (Bustamante and Castor 1998, Bustamante et al. 2005, Becerra and Simonetti 2013, Heinrichs et al. 2018). Therefore, our study shows possible patterns that may be expected in other similar landscapes where very little native forests remain. Other limitations in our study were the different isolation levels between fragments. This was an uncontrolled variable and probably contributed to the variability between fragments.

In conclusion, our results suggest that the replacement of this native forest by pine plantations has had a more important effect on native plant communities than fragmentation in this region. The fact that native species have not strongly been affected by fragmentation reinforces the idea that small fragments are of high conservation value at a landscape scale (sensu Fahrig 2017), as they hold high 
levels of native biodiversity and ought to be included in conservation plans of the Chilean temperate forests (Grez et al. 2006). Finally, our results also suggest that Pinus radiata plantations may be inhabited by a high proportion (at least $50 \%$ ) of native species of this area, and hence, because pine plantations will continue being present in this region, an appropriate management system in them may also contribute to conservation of native flora.

\section{ACKNOWLEDGEMENTS}

Field work as well as the studies from which information was gathered were financed by FONDECYT 1010802, 1050745, 1095046 and 1140657. We are thankful to CONAF and Masisa S.A. for allowing us to work on their states. We also thank professor Luis Faúndez for helping in taxonomic identification. $\mathrm{PB}$ also thanks project FB 0002-2014.

\section{REFERENCES}

Armesto JJ, R Rozzi, P León-Lobos. 1995. Ecología de los bosques chilenos: síntesis y proyecciones. In Armesto JJ, C Villagrán, MTK Arroyo eds. Ecología de los Bosques Nativos de Chile. Editorial Universitaria. p. 405-412.

Atmar W, B Patterson. 1995. The nestedness temperature calculator: a visual program, including 294 presence-absecnce matrices. Chicago, IL, USA. AISC Reserch, Inc. University Park and The Field Museum.

Becerra PI, J Simonetti. 2013. Patterns of exotic species richness of different taxonomic groups in a fragmented landscape of central Chile. Bosque 34(1): 45-51. DOI: 10.4067/S0717$\underline{92002013000100006}$

Benítez-Malvido J, M Martínez-Ramos. 2003. Impact of forest fragmentation on Understory plant species richness in Amazonia. Conservation Biology 17: 389-400. DOI: 10.1046/j.1523-1739.2003.01120.x

Brockerhoff E, C Ecroyd, A Leckie, M Kimberley. 2003. Diversity and succession of adventive and indigenous vascular understorey plants in Pinus radiata plantation forests in New Zealand. Forest Ecology and Management 185: 307-326. https://www.semanticscholar.org/paper/Diversity-and-succession-of-adventive-and-vascular-Brockerhoff-Ecroyd/ e7e2823a2d4079283a97820affafd2d56c5f8763

Brothers T, A Spingarn. 1992. Forest fragmentation and alien plant invasion of central Indiana Old-growth forests. Conservation Biology 6: 91-100. https://www.jstor.org/ stable $/ 2385854$ ?seq $=1$

Bustamante R, C Castor. 1998. The decline of an endangered temperate ecosystem: the ruil (Nothofagus alessandrii) forest in central Chile. Biodiversity and Conservation 7: 1607-1626. https://link.springer.com/article/10.1023 /A:1008856912888

Bustamante R, JA Simonetti, AA Grez, J San Martín. 2005. Fragmentación y dinámica de regeneración del bosque maulino: Diagnóstico actual y perspectivas futuras. In Smith-Ramírez C, JJ Armesto, C Valdovinos, eds. Historia, Biodiversidad y Ecología de los Bosques Costeros de Chile. Editorial Universitaria, Santiago, Chile. 555-564 p.
http://bdrnap.mma.gob.cl/recursos/SINIA/Biblio AP/070316BIBLIORNAP 164.pdf

Chen J, J Franklin J, T Spies. 1995. Growing-season microclimatic gradients from clearcut edges into old-growth Douglas-Fir forests. Ecological Applications 5: 74-86. https:// andrewsforest.oregonstate.edu/sites/default/files/lter/pubs/ pdf/pub2095.pdf

Decocq G, M Aubert, F Dupont, D Alard, R Saguez, A WattezFranger, B De Foucault, A Delelis-Dusollier, J Bardat. 2004. Plant diversity in a managed temperate deciduous forest: understory response to two silvicultural systems. Journal of Applied Ecology 41: 1065-1079. DOI: https:// doi.org/10.1111/j.0021-8901.2004.00960.x

Di Castri F, E Hajek. 1976. Bioclimatología de Chile. Santiago, Chile. Ediciones Universidad Católica de Chile. 128 p. https://www.ecolyma.cl/documentos/bioclimatologia_de chile.pdf

Didham R, J Lawton. 1999. Edge structure determines the magnitude of changes in microclimate and vegetation structure in tropical forest fragments. Biotropica 31: 17-30. DOI: https://doi.org/10.1111/j.1744-7429.1999.tb00113.x

Echeverría C, AC Newton, A Lara, JM Rey-Benayas, DA Coomes. 2007. Impacts of forest fragmentation on species composition and forest structure in the temperate landscape of southern Chile. Global Ecology and Biogeography 16: 426439. DOI: $10.1111 /$ j.1466-8238.2007.00311.x

Fahrig L. 2017. Ecological responses to habitat fragmentation per se. Annual Review of Ecology, Evolution and Systematics 48: 1-23. DOI: 10.1146/annurev-ecolsys-110316-022612

García V, JA Simonetti, PI Becerra. 2016. Lluvia de semillas, depredación de semillas y germinación de especies nativas en plantaciones de Pinus radiata en Chile centro-sur: efecto de la distancia a bosque nativo y presencia de sotobosque. Bosque 37(2): 359-367. DOI: $10.4067 / \mathrm{S} 0717-$ $\underline{92002016000200014}$

Gómez P, S Hahn, J San Martín. 2009. Estructura y composición florística de un matorral bajo plantaciones de $P i$ nus radiata D. Don en Chile central. Gayana Botanica 66: 256-268. DOI: http://dx.doi.org/10.4067/S0717$\underline{66432009000200010}$

González-Moreno P, J Pino, N Gassó, M Vila. 2013. Landscape context modulates alien plant invasion in Mediterranean forest edges. Biological Invasions 15: 547-557. DOI $\underline{10.1007 /}$ $\underline{\text { s10530-012-0306-X }}$

Groom M, N Schumaker. 1993. Evaluating landscape change: patterns of worldwide deforestation and local fragmentation. In Kareiva P, J Kingsolver, R Huey, eds. Biotic interactions and global change. Sinauer, Sunderland. p. 24-44.

Guirado M, J Pino, F Roda. 2006. Understorey plant species richness and composition in metropolitan forest archipielagos: effects of forest size, adjacent land use and distance to the edge. Global Ecology and Biogeography 15: 50-62. DOI: 10.1111/j.1466-822x.2006.00197.x

Halpern C, T Spies. 1995. Plant species diversity in natural and managed forests of the pacific northwest. Ecological Applications 5: 913-934. DOI: 10.2307/2269343

Heinrichs S, A Pauchard, P Schall. 2018. Native Plant Diversity and Composition Across a Pinus radiata D. Don Plantation Landscape in South-Central Chile-The Impact of Plantation Age, Logging Roads and Alien Species. Forests 9: 567. DOI: $10.3390 / \mathrm{f} 9090567$ 
Higgins C, MR Willig, R Strauss. 2006. The role of stochastic processes in producing nested patterns of species distributions. Oikos 114: 159-167. DOI: https://doi.org/10.1111/ j.2006.0030-1299.14720.x

Hobbs R. 2001. Synergisms among habitat fragmentation, livestock grazing, and biotic invasions in Southwestern Australia. Conservation Biology 15: 1522-1528.

DOI: $10.1046 / \mathrm{j} .1523-1739.2001 .01092 . \mathrm{x}$

Hobbs R, L Huenneke. 1992. Disturbance, diversity, and invasions: implications for conservation. Conservation Biology 6: 324-337. https://www.jstor.org/stable/2386033?seq=1

Honnay O, M Hermy, P Coppin. 1999. Nested plant communities in deciduous forest fragment: species relaxation or nested habitats? Oikos 84: 119-129. DOI: 10.2307/3546872

Laurance W, L Ferreira, J Rankin-de Merona, S Laurance. 1998. Rain forest fragmentation and the dynamics of Amazonian tree communities. Ecology 79: 2032-2040. DOI: $\underline{10.2307 / 176707}$

Murcia C. 1995. Edge effects in fragmented forests: implications for conservation. Trends in Ecology and Evolution 10: 5862. DOI: $10.1016 / \mathrm{S} 0169-5347(00) 88977-6$

Patterson B. 1990. On the temporal development of nested subset patterns of species composition. Oikos 59: 330-342. DOI: $10.2307 / 3545143$

Rodríguez R, C Marticorena, D Alarcón, C Baeza, L Cavieres, VL Finot, N Fuentes, A Kiessling, M Mihoc, A Pauchard, E Ruiz, P Sánchez, A Marticorena. 2018. Catálogo de las plantas vasculares de Chile. Gayana Botanica 75(1): 1-430. http://www.gayanabotanica.cl/pdfs/2018/1/01 Rodriguez etal 2018.pdf

Rojas I, PI Becerra, N Gálvez, J Laker, C Bonacic, A Hester. 2011. Relationship between fragmentation, degradation and native and exotic species richness in an Andean temperate forest of Chile. Gayana Botanica 68(2): 163-175. https:// www.academia.edu/23865948/Relationship between fragmentation degradation and native and exotic species richness in an Andean temperate forest of Chile

Silveri A, P Dunwiddie, H Michaels. 2001. Logging and edaphic factors in the invasion of an Asian woody vine in a mesic North American forest. Biological Invasions 3: 379-389. DOI: 10.1023/A:1015898818452

Vandermeer J, R Carvajal. 2001. Metapopulation dynamics and the quality of the matrix. American Naturalist 158: 211220. DOI: $\underline{10.1086 / 321318}$ 